\title{
Global funksjonsskåring - like aktuelt etter siste versjon av diagnosesystemet DSM
}

\author{
Global Assessment of Functioning (GAF) er et mål på psykososialt funksjonsnivå og brukes på tvers av psy- \\ kiatriske diagnoser. Selv om skalaen er tatt ut av siste versjon av diagnosesystemet Diagnostic and Statistical \\ Manual of Mental Disorders (DSM), betyr ikke dette at den forsvinner som klinisk konstruksjon. Den er fort- \\ satt aktuell som dokumentasjon av klinisk virksomhet. Likevel er det på tide med en modernisering.
}

Global Assessment of Functioning (GAF) er et mål på psykososialt funksjonsnivå, spesielt utviklet for psykiske lidelser. I forrige versjon av DSM, DSM-IV (1), representerer GAF-skalaen et dimensjonalt supplement til de ellers kategoriske klassifikasjonene. Skalaen er et generisk instrument for sykdomsalvorlighetsgrad, og den er ikke diagnosespesifikk.

I psykiatrien har det vært tradisjon for global funksjonsmåling siden 1960-årene. Det hele startet med Health-Sickness Rating Scale (HSRS) (2) som fikk en videreutvikling med Global Assessment Scale (GAS) (3). Disse er forløperne til GAF-skalaen, som først i 1987 ble innført med diagnosesystemet DSM-III-R. I 2013 kom den nye versjonen av DSM (DSM-5). Her er aksesystemet fra DSM-IV fjernet. Dermed er også GAF-skalaen, som utgjorde akse V, blitt borte (4).

\section{Global funksjonsmåling}

Det ble tidlig reist innvendinger mot GAFskalaen. I hovedsak gjaldt innvendingene bruken av kun ett tall for å angi alvorlighetsgrad av både symptomer og funksjonsnivå. På slutten av 1990-årene ble den norske oversettelsen av GAF-manualen splittet i to, med én skala for symptomnivå og én for funksjonsnivå. Disse ble så skåret hver for seg.

Det ble også utarbeidet en egen veiledning for bruk av GAF-skalaen (5), dessuten ble det med støtte fra Statens helsetilsyn utviklet et nettbasert opplæringsprogram (6). På samme tid ble den tatt inn som en del av «minste basisdatasett», som Statens helsetilsyn anbefalte psykiatriske institusjoner å bruke (7).

Som målemetode har GAF-skalaen vist seg å være svært pålitelig dersom brukeren har fătt enkel opplæring (8). Den kliniske nytten av å splitte skalaen er også nylig dokumentert (9). Ved å gjenspeile alvorlighetsgrad utgjør skalaen en viktig tilleggsinformasjon til de ellers kategoriske diagnosene, og den lange tradisjonen med dette målet bekrefter dens betydning.

\section{Ingen gode alternativer så langt}

Som erstatning for GAF-skalaen har American Psychiatric Association (10) foreslått å benytte WHO Disability Assessment Schedule (WHODAS) (11). Dette instru- mentet er et generelt mål for helse og dysfunksjon og omfatter seks områder: kognisjon, mobilitet, selvomsorg, omgang med mennesker, aktivitet i dagliglivet, sosial deltakelse.

I mange tilfeller vil, etter mitt skjønn, de områdene som WHODAS måler ikke være relevante for pasienter med moderate til alvorlige mentale lidelser og vil dermed ha åpenbare begrensninger som endringsmål for sykdomsalvorlighetsgrad. Det er, slik

\section{«GAF-skalaen er en klinisk konstruksjon, uten noen naturlig måleenhet eller måleskala»}

jeg ser det, lite sannsynlig at dette instrumentet vil erstatte GAF-skalaen som rutinemessig mål innen psykisk helsevern. Det er mer i tråd med instrumenter som skal gjenspeile generell helse og livskvalitet. Per i dag finnes det altså ikke noe godt alternativ til GAF-skalaen.

\section{Begrensninger ved GAF-skalaen}

GAF-skalaen har vist sin relevans på alle nivåer av mental lidelse/helse, men det hefter likevel en del utfordringer til metoden. For eksempel viste Vatnaland og medarbeidere at det er stor uenighet mellom uerfarne skårere og mellom uerfarne og erfarne skårere (12). Dessuten representerer ikke den originale GAF-manualen, slik den er operasjonalisert, en kontinuerlig hypotetisk størrelse, noe som åpner for ulik bruk av skalaen.

GAF-skalaen er en metode, og i likhet med andre metoder må den læres. Dette var også ett av hovedargumentene for ikke å beholde den i DSM-5, der det eksplisitt ble vist til bekymring over at pålitelig GAFskåring var avhengig av spesiell opplæring (10). I likhet med alle andre kliniske evalueringer må slik kompetanse læres før skårerne kan bli reliable og valide, så kravet til opplæring er derfor i seg selv et dårlig argument for å fjerne GAF-skalaen.
Da Health-Sickness Rating Scale kom i begynnelsen av 1960-årene kom Luborsky (2) med presiseringer av de aspekter ved mental helse som det skulle settes søkelys på samt konkrete retningslinjer for skåringene. Det var ingen som hadde gjort noe tilsvarende for GAS- eller GAF-skalaen før Karterud og medarbeidere utarbeidet sin veiledning og gjorde den offentlig tilgjengelig i 1998 (5). Denne var i første rekke ment å gi noen etterlengtede retningslinjer, men også bidra til en felles praksis rundt metoden.

Den gang ble det ikke gjort noe med selve GAF-manualen, bortsett fra noen kommentarer i margen som skulle presisere alvorlighetsgraden. Således er det fortsatt forbedringspotensial ved skalaen slik vi kjenner den i dag (13). Dette gjelder spesielt en rekke uklare operasjonaliseringer, stikkord og ankerpunkter, noe som åpner for stort tolkingsrom og dermed dårlig reliabilitet og svekket klinisk verdi. Vi så et eksempel på dette i den første sakkyndighetserklæringen i Breivik-saken, der GAFskalaen ble skåret ekstremt lavt, noe som førte til innsigelser fra fagmiljøene og debatt i mediene (14-16).

I GAF-manualen angis det at man forestiller seg «en hypotetisk kontinuerlig skala for mental helse/sykdom» (1). Dette innebærer at konkrete symptomer og sosial fungering ikke må betraktes isolert, men må ses i lys av en større helhet og ha klinisk relevans. Slik det er formulert i den nåværende manualen, kan det fort gå galt.

Ett eksempel på dette er finner vi ved det lave området på skalaen for å angi symptomnivå. Her er det angitt som stikkord: «Fare for å kunne skade seg selv eller andre...» Dette er uheldig og åpner for en anvendelse av GAF-skalaen som bryter med den overordnede ideen om en kontinuerlig skala. Fare for å kunne skade seg selv eller andre kan også være til stede hos personer lenger oppe på GAF-skalaen, ikke bare i den nedre delen. Sammen med stikkord om selvmordsfare er dette eksempler der manualen eksemplifiserer en atferd eller et symptom som egentlig ikke har noe med GAF-skalaen å gjøre. Den er verken et mål på graden av selvmordsfare eller fare for voldsutøvelse eller trussel mot andres liv. 


\section{Behov for felles forståelse}

GAF-skalaen er en klinisk konstruksjon, uten noen naturlig måleenhet eller måleskala. Det er rett og slett noe vi forestiller oss, og da er det helt avgjørende at vi har samme forestilling. Det må derfor etableres en slik felles forståelse og utarbeides felles retningslinjer for skåring som er i tråd med tanken om at skalaen er en kontinuerlig størrelse. Dette krever etablering av undervisningsprogrammer som er mer moderniserte og samkjørte enn det som finnes i dag.

Kanskje det aller viktigste og mest avgjørende er å få etablert en forståelse av GAFskalaen som en kontinuerlig størrelse fra 1 til 100, der 1 representerer den verst tenkelige alvorlighetsgrad av symptombelastning og psykososialt funksjonsnivå og $100 \mathrm{det}$ best tenkelige nivå av mental helse og psykososial fungering. Om en slik hypotetisk skala skal kunne fange opp all observerbar variasjon, ligger det implisitt at toppen (en skår på 99-100) og bunnen (en skår på 1-2) i praksis bare er teoretiske størrelser.

Det er ikke mulig bare å lese seg til en slik forståelse. Reliable og valide GAF-skåringer er helt avhengig av øvelse, klinisk erfaring og, ikke minst, kalibrering i form av diskusjoner med kolleger. Det er bare gjennom denne prosessen at GAF-skalaen kan få styrket kvalitet som en nyttig metode og en klinisk informasjonsbærer. Lar vi være å ta dette på alvor, vil de fortsatt ha rett som kaller denne metoden for «GAF-dart».

\section{Opplæring og retningslinjer}

Norge har vært et foregangsland når det gjelder opplæring, kvalitetssikring og forskning på GAF-skalaen. Siden slutten av 1990-årene har opplæring i bruken vært gitt i regi av DagbehandlingsNettverk (17) til behandlingsinstitusjoner i alle helseregionene der man har ønsket dette. Opplæringen har vært organisert som heldagskurs hvor deltakerne har fått teoretisk kunnskap og praktisk erfaring med metoden. I de senere år er det avholdt ett GAF-kurs hvert semester ved Seksjon for personlighetspsykiatri, Klinikk psykisk helse og avhengighet, Oslo universitetssykehus. Ansvaret for dette deles nå mellom DagbehandlingsNettverk og Norsk kompetansetjeneste for personlighetspsykiatri (NAPP).

I dag har mange helseforetak egne ressurspersoner som gir veiledning og undervisning i GAF-skåring. Det finnes ingen samkjøring av denne undervisningen i Norge, men snarere en rekke lokale variasjoner av retningslinjer for skåring, gjerne spesielt tilpasset bestemte pasientgrupper. Dette er uheldig, da det etablerer ulik praksis rundt både forståelse og skåring av GAF-skalaen.

\section{Behov for modernisering}

Det er ingen grunn til å anse GAF-skalaen som historie bare som følge av American Psychiatric Associations pennestrøk, men det er likevel på tide med en modernisering. Dette krever i prinsippet to enkle grep: En internasjonal revisjon av den originale manualen (1) og veiledningen fra 1998 (5) og en standardisering av lett tilgjengelige videobaserte undervisningsprogrammer, fritt tilgjengelige for helsepersonell. Arbeidet med denne forbedringen er nå godt i gang ved Seksjon for personlighetspsykiatri, Oslo universitetssykehus. En organisering av dette «GAF-prosjektet» vil være basert på et både nasjonalt og internasjonalt samarbeid.

\section{Geir A. Feigum Pedersen}

geir.pedersen@medisin.uio.no

Geir Pedersen (f. 1962) er ph.d, enhetsleder og seniorforsker ved Seksjon for personlighetspsykiatri, Klinikk psykisk helse og avhengighet, Oslo universitetssykehus, og daglig leder for Nettverk for Personlighetsfokuserte Behandlingsprogrammer i Norge (DagbehandlingsNettverk)

Forfatter har fylt ut ICMJE-skjemaet og oppgir ingen interessekonflikter.

\section{Litteratur}

1. American Psychiatric Association. Diagnostic and statistical manual of mental disorders. 4. utg. Washington, D.C.: American Psychiatric Association, 1994.
2. Luborsky L. Clinician's judgments of mental health. Arch Gen Psychiatry 1962; 7: 407-17.

3. Endicott J, Spitzer RL, Fleiss JL et al. The global assessment scale. A procedure for measuring overall severity of psychiatric disturbance. Arch Gen Psychiatry 1976; 33: 766-71

4. American Psychiatric Association. Diagnostic and Statistical Manual of Mental Disorders. 5. utg. Arlington, VA: American Psychiatric Publishing, 2013

5. Karterud S, Pedersen G, Løvdahl H, et al. Global Assessment of Functioning - split version. Background and scoring guidelines. Oslo: Psykiatrisk avdeling, Oslo universitetssykehus, Ullevål, 1998.

6. Pedersen G, Karterud S. Global Assessment of Functioning - split version. Norwegian Internet training program, 1998 http://personlighetsprosjekt.com/gaf/ (1.2.2014).

7. Statens helsetilsyn. Håndbok i drift av psykiatriske poliklinikker. Statens helsetilsyns utredningsserie 2-2001. IK 2739. Oslo: Statens helsetilsyn, 2001.

8. Pedersen G, Hagtvet KA, Karterud S. Generalizability studies of the Global Assessment of Functioning (GAF) - split version. Compr Psychiatry 2007; 48: 88-94.

9. Pedersen G, Karterud S. The symptom and function dimensions of the Global Assessment of Functioning (GAF) scale. Compr Psychiatry 2012; 53: $292-8$

10. American Psychiatric Association. 2013. Insurance Implications of DSM-5. www.psych.org/ File\%20Library/Practice/DSM/DSM-5/ Insurance-Implications-of-DSM-5.pdf (25.3.2014).

11. Üstün TB, Kostanjsek N, Chatterji S et al. Measur ing Health and Disability. Manual for WHO Disability Assessment Schedule (WHODAS 2.0). Genève: World Health Organization, 2010.

12. Vatnaland T, Vatnaland J, Friis $S$ et al. Are GAF scores reliable in routine clinical use? Acta Psychiatr Scand 2007; 115: 326-30

13. Aas IH. Global Assessment of Functioning (GAF): properties and frontier of current knowledge. Ann Gen Psychiatry 2010; 9: 20.

14. Foss AB, Johansen PA, Andreassen TA. Breivik fikk 2 av 100 mulige poeng i psykiatrisk test. Aftenposten 3.12.2011. www.aftenposten.no/nyheter/ iriks/Breivik-fikk-2-av-100-mulige-poeng-ipsykiatrisk-test-6712735.html\#.UzF23KIVAs0 (25.3.2014)

15. Gardell M. Galna slutsatser. Aftonbladet 7.12.2011. www.aftonbladet.se/kultur/article14042903.ab (25.3.3014)

16. Kissane K. Mad or bad? The jury is out. The Sydney Morning Herald 14.4.2012. www.smh.com.au/ world/mad-or-bad-the-jury-is-out-20120413-1 wyvg.html (25.3.2014).

17. DagbehandlingsNettverk. www. dagbehandlingsnettverk.no/ (7.4.2014).

Mottatt 11.2. 2014, første revisjon innsendt 26.3 2014, godkjent 7.4 2014. Redaktør: Kari Tveito.

Publisert først på nett. 